\title{
The Use of Environmentally and Online-Based Media and Its Effect on PAI Learning Outcomes
}

\author{
Jaswati. Z \\ Guru Pendidikan Agama Islam SD Negeri 09 Enam Lingkung Padang Pariaman \\ jasmawati@yahoo.com
}

ARTICLE INFO

\section{Article History:}

Received: June 25,2021

Revised: July 10, 2021

Accepted: July 23, 2021

Published: October 31, 2021

\section{*Corresponding}

Author:

Name:Jasmawati. Z

Email:jasmawati@yaoo

.com

Phone/WA

081374288856

Keyword

\section{ABSTRACT}

Learning media has an important position for the achievement of learning outcomes, theoretically there are various types of media that are commonly used, therefore, researchers want to analyze the implementation of PAI learning using environmental-based and online-based learning media and their effect on PAI learning outcomes in state elementary schools. The collected data is analyzed using SPSS Version 20.0 through the Classical Assumption Test, Percentage Descriptive Analysis, T (partial) and F (simultaneous) Test. The results showed pai learning using Environmental-Based Media and Online supports the effective implementation of learning. This is evident from the percentage of respondents' answers of $90.83 \%$ for environmentally based media and $90.14 \%$ for online-based media. Based on the constant value of PAI Learning Media Based Environment and Online Based which amounted to 81,289 . This constant value means, if there is no Environmentally Based and Online-Based PAI Learning Media, then a consistent value of Learners' Learning Outcomes of 81,289 will not appear.

Environmentally; Online; Media; Learning Outcome; Islamic Education

\section{Abstrak}

Media pembelajaran memiliki posisi penting untuk pencapaian hasil pembelajaran, secara teoritis terdapat berbagai jenis media yang biasa digunkan, oleh karenanya, peneliti berkeinginan untuk menganalisa pelaksanaan pembelajaran PAI dengan menggunakan media pembelajaran berbasis lingkungan dan berbasis online serta pengaruhnya terhadap hasil belajar PAI di SD Negeri. Data yang terkumpul dianalisis dengan menggunakan SPSS Versi 20.0 melalui Uji Asumsi Klasik, Analisis Deskriptif Presentase, Uji T (parsial) dan Uji F (simultan). Hasil penelitian menunjukkan pembelajaran PAI dengan menggunakan Media Berbasis Lingkungan dan Online mendukung terlaksananya pembelajaran secara efektif. Hal ini terlihat dari presentase jawaban responden sebesar $90.83 \%$ untuk media berbasis lingkungan dan 90.14\% untuk media berbasis online. Berdasarkan nilai konstan Media Pembelajaran PAI Berbasis Lingkungan dan Berbasis Online yang sebesar 81.289. Nilai konstan ini memiliki arti, jika tidak ada Media Pembelajaran PAI Berbasis Lingkungan dan Berbasis Online, maka nilai konsisten Hasil Belajar Peserta didik sebesar 81.289 tidak akan muncul. 


\section{INTRODUCTION}

Penggunaan media pembelajaran dalam mengajarkan materi Pendidikan Agama Islam bukanlah sekedar upaya untuk membantu guru, namun juga membantu peserta didik dalam belajar (Yanuari Dwi Puspitarini \& Hanif, 2019; Andria Rosa et al., 2020) . Penggunaan media akan membantu peserta didik untuk lebih fokus pada apa yang disampaikan oleh guru dapat meningkatkan pemahaman peserta didik (Ritonga et al., 2021; Susanti et al., 2020), serta dapat menerima pesan dengan baik dan benar. Oleh karena itu, penggunaan media sangat dianjurkan dalam mengembangkan pembelajaran Pendidikan Agama Islam.

Beberapa hal harus diperhatikah oleh seorang guru dalam menentukan media pembelajaran (Marpanaji et al., 2018; Ramdhani \& Muhammadiyah, 2015). Pertama, untuk siapa media pembelajaran dibuat, untuk anak-anak (tingkat Sekolah Dasar) atau untuk orang dewasa (SMP/SMA). Kedua, karekteristik peserta didik yang akan dijadikan sasaran. Ketiga, guru harus memperhatikan prinsip-prinsip dalam penggunaan media. Penggunaan media adalah untuk menyampaikan pesan sehingga pembelajaran PAI akan lebih dihayati tanpa menimbulkan kesalahpahaman bagi peserta didik dan guru. Peserta didik akan dapat menangkap materi pelajaran PAI dengan mudah, efektif, dan dapat dicerna dengan baik.

Media pembelajaran Pendidikan Agama Islam adalah perantara atau pengantar pesan guru agama kepada peserta didik. Media pembelajaran ini sangat diperlukan dalam merangsang pikiran, perasaan, perhatian, dan minat peserta didik, sehingga terjadi proses belajar mengajar serta dapat memperlancar penyampaian materi Pendidikan Agama Islam (Sartika et al., 2020). Oleh karena itu, pembelajaran harus didesain sedemikian rupa, khususnya pembelajaran Pendidikan Agama Islam (PAI), agar kegiatan pembelajaran dapat memacu belajar peserta didik menjadi lebih aktif dan berpusat pada peserta didik (student centered), maka diperlukan metode, strategi, sumber belajar, model dan yang tidak kalah penting adalah media pembelajaran. Media pembelajaran tidak hanya menjadikan belajar lebih aktif, akan tetapi juga akan menambah kegairahan sekaligus menghargai perbedaan individu dan beragamnya kecerdasan peserta didik.

Media pembelajaran secara teoritis terdiri dari berbagai jenisnyaseperti: 1) media grafis, 2) media tiga dimensi, 3) media proyeksi penggunaan, dan 4) lingkungan sebagai media pendidikan (Risnawati et al., 2018; Khaira et al., 2021). Media pembelajaran ada yang sederhana dan murah hingga media pembelajaran yang canggih dan mahal (Mardikaningrum et al., 2017; Thompson et al., 2014). Dari mulai rakitan pabrik hingga buatan tangan para guru itu sendiri, bahkan ada pula yang telah disediakan oleh alam di lingkungan sekitar yang dapat langsung digunakan sebagai media pembelajaran.

Atas dasar pemahaman tersebut di atas, maka diharapkan tidak ada lagi argumentasi yang muncul di kalangan para guru untuk tidak dapat menggunakan alat 
peraga oleh karena biayanya mahal. Begitu banyaknya lingkungan sekitar yang dapat digunakan sebagai media alat peraga tanpa perlu biaya mahal. Beberapa benda di lingkungan dapat dimanfaatkan sebagai sumber belajar, baik yang dimanfaatkan secara langsung (by utility resources), ataupun yang dirancang terlebih dahulu (by design resources) dan dapat pula dengan cara rekayasa media.

Pada dasarnya semua lingkungan yang ada di sekitar peserta didik dapat dimanfaatkan untuk mengoptimalkan kegiatan pembelajaran sepanjang relevan dengan kompetensi dasar dan hasil belajar yang diharapkan (Grabinger \& Dunlap, 1995). Dari semua lingkungan yang dapat digunakan dalam proses pendidikan dan pembelajaran secara umum dapat dikategorikan menjadi tiga macam lingkungan belajar yakni lingkungan alam, lingkungan sosial dan lingkungan buatan.

Sesuai dengan kondisi pembelajaran di SD Negeri 09, serta keberadaan lingkungan sebagai media pembelajaran. Maka penelitian ini bertujuan untuk menganalisis lebih dalam terkait penggunaan media berbasis lingkungan serta berbasis teknologi untuk pembelajaran PAI.

\section{METHOD}

Jenis penelitian ini adalah penelitian (field research) kuantitatif dengan menggunakan pendekatan deskriptif exsplanatory. Peneliti hanya melakukan pengukuran terhadap kenyataan sebagaimana adanya tanpa melakukan manipulasi perlakuan atau subjek. Populasi penelitian ini adalah seluruh peserta didik SD Negeri 09 Enam Lingkung Kabupaten Padang Pariaman yang berjumlah 109 orang dengan sampel penelitian sebanyak 27 orang. Pengambilan sampel dilakukan dengan menggunakan teknik porpusive sampling.

Variabel penelitian ini terdiri dari variabel bebas dan variabel terikat, yaitu: a) Variabel bebas: Media Pembelajaran PAI Berbasis Lingkungan $\left(\mathrm{X}^{1}\right)$ dan Media Pembelajaran PAI Berbasis Online $\left(\mathrm{X}^{2}\right)$, b) Variabel terikat: Hasil Belajar (Y) .

Instrumen dalam penelitian ini berupa angket yang berisi pernyataan menggunakan model skala Likert dengan lima alternatif dan skor selalu $(\mathrm{SL}=5)$, sering $(\mathrm{SR}=4)$, kadang-kadang $(\mathrm{KD}=3)$, jarang $(\mathrm{JR}=2)$, dan tidak pernah $(\mathrm{TP}=1)$. Setelah angket tersusun berdasarkan indikator, maka angket diujikan kepada 12 orang responden di luar sampel dan dilakukan uji validitas dan reliabilitas dengan menggunakan SPSS versi 20.0, lalu pernyataan yang tidak valid dibuang. Setelah itu agket dibagikan kepada 27 orang sampel. Setelah data terkumpul, maka data tersebut di analisis dengan menggunakan SPSS versi 20.0. Metode analisis yang digunakan adalah: analisis deskriptif persentase, uji asumsi klasik (uji normalitas data, uji heteroskedastisitas, dan histogram), uji nilai signifikan, uji parsial (Uji T), dan uji simultan (Uji F).

\section{RESULTS\&DISCUSSION}

SD Negeri 09 Enam Lingkung Kabupaten Padang Pariaman telah menerapkan lingkungan sebagai media pembelajaran Pendidikan Agama Islam. SD Negeri 09 Enam 
Lingkung ini berada di daerah terisolir, memiliki sarana prasarana apa adanya serta jauh dari jangkauan jaringan internet. Kondisi ini mendorong guru Pendidikan agama Islam menjadikan alam/lingkungan sebagai media pembelajaran Pendidikan Agama Islam. Pembelajaran Pendidikan Agama Islam berbasis lingkungan ini menjadi kegiatan yang menyenangkan bagi peserta didik, karena mereka diajak oleh guru Pendidikan Agama Islam belajar sambil bermain. Lingkungan menjadi media pembelajaran yang interaktif, menarik dan efektif, dan tentu diharapkan mampu meningkatkan prestasi belajar peserta didik.

Di samping itu, melalui media lingkungan guru sangat mudah memberikan pemahaman kepada peserta didik dalam menjaelaskan berbagai materi Pendidikan Agama Islam. Pembelajaran berbasis lingkungan adalah suatu pembelajaran yang menggunakan objek belajar sebagai pengalaman nyata, mengamati secara langsung, memperoleh data-data secara akurat, dan dapat belajar secara mandiri ataupun berkelompok.

Pada masa Covid-19, SD Negeri 09 Enam Lingkung Kabupaten Padang Pariaman meniadakan pembelajaran dalam kelas, pembelajaran dilakukan lewat online. Pemerintah melalui Kemendikbud RI memperpanjang masa pembukaan sekolah dengan belajar tatap muka sampai Desember 2020 dan akan dibuka kembali pada bulan Januari 2021, jika wabah Covid-19 sudah semakin membaik. Tiga diantara model pembelajaran dimasa pandemi Covid-19 yang boleh dipergunakan adalah daring, luring, dan home visit, walaupun pembelajaran daring atau dalam jaringan (pembelajaran jarak jauh) pada umumnya tidak disukai peserta didik.

Hampir $76 \%$ peserta didik tidak menyukai pembelajaran daring ini, dengan alasan tidak memiliki kuota, apa lagi peserta didik SD Negeri 09 Enam Lingkung yang tidak memiliki HP android, dan kesulitan dalam menggunakan video, serta kesulitan signal. Di SD Negeri 09 Enam Lingkung Kabupaten Padang Pariaman, pembelajaran daring tetap dilakukan dengan format baru yang menyenangkan bagi peserta didik, yaitu dengan membuat konten video yang dilakukan oleh masing-masing guru. Pembelajaran daring ini dilakukan bukan berarti tanpa kendala. Tentu kendala yang dihadapi sangat banyak mengingat kegiatan ini mendadak yang tidak direncanakan dalam kurikulum. Beberapa guru yang melek teknologi tentu saja cepat memikirkan bagaimana melaksanakan pembelajaran daring yang efektif, dimana peserta didik tetap dapat melaksanakan pembelajaran mencakup ranah afektif, kognitif, dan psikomotorik sekaligus di rumah.

Dari segi peserta didik, tentunya mereka akan keberatan jika diberi tugas yang banyak. Wajar, apalagi jika anak usia SD. Mereka masih suka bermain dengan temannya. Maka guru harus pintar memmilih tugas agar peserta didik tidak jenuh. Tugas tidak hanya mengerjakan soal saja, karena ranah apektif, psikomotorik juga perlu dikembangkan apalagi dalam lingkungan rumah, hal ini jarang dieksplor ketika pembelajaran biasa. Daring merupakan singkatan dari "dalam jaringan" sebagai pengganti kata "online" yang sering digunakan dalam kaitannya dengan teknologi internet. Daring adalah terjemahan dari istilah online yang bermakna tersambung ke 
dalam jaringan internet. Pembelajaran dari artinya pembelajaran yang dilakukan secara online dengan menggunakan aplikasi pembelajaran maupun jejaring sosial. Pembelajaran daring merupakan pembelajaran yang dilakukan tanpa tatap muka, tetapi melalui flatform yang tersedia atau dengan menggunakan jajaring sosial. Segala bentuk materi pembelajaran didistribusikan secara online, komunikasi juga dilakukan secara online, atau ujian pun dilaksanakan secara online.

Media Pembelajaran PAI Berbasis Lingkungan. Berdasarkan jawaban responden penelitian diperoleh jumlah total skor jawaban responden tentang Penerapan Media Pembelajaran PAI Berbasis Lingkungan di SD Negeri 09 Enam Lingkung Kabupaten Padang Pariaman sebesar 3.188. Jumlah total skor ideal jawaban responden sebesar 3.510 , dengan tingkat presentase sebesar $90.83 \%$. Tingkat presentase jumlah total skor jawaban responden berada pada rentang $84.75 \%<$ skor $\leq 100 \%$, dengan kriteria sangat baik. Dengan demikian dapat disimpulkan bahwa penerapan Media Pembelajaran PAI Berbasis Lingkungan di SD Negeri 09 Enam Lingkung Kabupaten Padang Pariaman berjalan dengan sangat baik.

Media Pembelajaran PAI Berbasis Online. Berdasarkan jawaban responden penelitian diperoleh jumlah total skor jawaban responden tentang penerapan Media Pembelajaran PAI Berbasis Online di SD Negeri 09 Enam Lingkung Kabupaten Padang Pariaman sebesar 1.582. Jumlah total skor ideal jawaban responden sebesar 1.755, dengan tingkat presentase sebesar $90.14 \%$. Tingkat presentase jumlah total skor jawaban responden berada pada rentang $84.75 \%<$ skor $\leq 100 \%$, dengan kriteria sangat baik. Dengan demikian dapat disimpulkan bahwa penerapan Media Pembelajaran PAI Berbasis Online di SD Negeri 09 Enam Lingkung Kabupaten Padang Pariaman berjalan dengan sangat baik.

Hasil Belajar PAI. Hasil belajar PAI ini berasal dari nilai akhir peserta didik yang menjadi sampel penelitian sebanyak 27 orang yang dipilih dari kelas IV dan V tahun pelajaran 2019/2020. Hasil Belajar ini diambil dari nilai tiga ranah, yaitu ranah afektif, kognitif, dan psikomotorik dengan jumlah total skor sebesar 2.261. Jumlah total skor ideal sebesar 2.700, dengan tingkat presentase sebesar $83.75 \%$. Tingkat Presentase Hasil Belajar PAI ini berada pada rentang $64.75 \%<$ skor $\leq 83.75 \%$, dengan kriteria baik. Dengan demikian dapat disimpulkan bahwa Hasil Belajar PAI di SD Negeri 09 Enam Lingkung Kabupaten Padang Pariaman, berada pada kriteria baik.

Setelah dilakukan uji normalitas data terhadap variabel Hasil Belajar PAI dengan menggunakan Plot of Regression Standardized Residual, maka diperoleh output SPSS Versi 20.0 sebagai berikut:

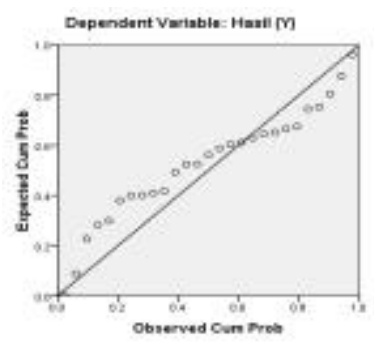

Gambar 1. Diagram Normal P-Plot Hasil Belajar PAI 
Berdasarkan hasil output SPSS pada Plot of Regression Standardized Residual, terlihat titik-titik mendekati garis diagonal, dengan demikian dapat disimpulkan bahwa variabel Hasil Belajar PAI memiliki model regresi berdistribusi normal.

Uji Heteroskedastisitas. Setelah dilakukan uji Heteroskedastisitas terhadap variabel Hasil Belajar PAI dengan menggunakan multivariate standardized Scatterplot, maka diperoleh output SPSS Versi 20.0 sebagai berikut:

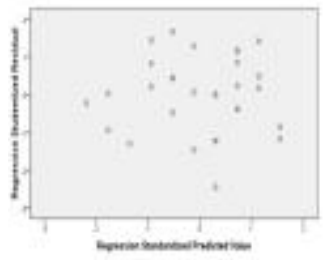

Gambar 2. Diagram Scatterplot

Berdasarkan diagram scatterplot di atas terlihat plot-plot tersebar merata di atas dan di bawah garis horizontal. Sebaran nilai residual terstandar tidak membentuk pola tertentu namun tampak random, maka dapat dikatakan bahwa model regresi variabel minat baca bersifat homogen atau tidak mengandung heteroskedastisitas.

Histogram, setelah dilakukan uji histogram terhadap variabel Hasil Belajar PAI dengan menggunakan Regression Standardized Residual, maka diperoleh output SPSS Versi 20.0 sebagai berikut:

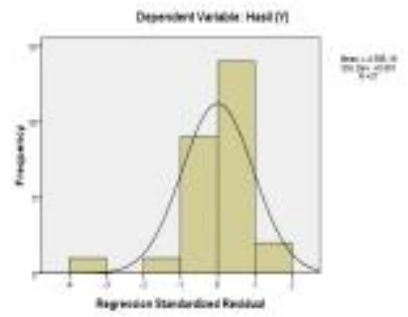

Gambar 3. Histogram

Pada gambar histogram di atas, terlihat garis melengkung ke atas seperti membentuk gunung. Apabila garis tersebut membentuk gunung dan terlihat sempurna dengan kaki yang simetris, maka dapat disimpulkan bahwa data dalam penelitian berdistribusi normal.

Berdasarkan pengujian persyaratan analisis penelitian yang telah dipaparkan di atas, maka pesyaratan pengujian regresi berganda dapat terpenuhi. Rumus persamaan regresi berganda adalah $\mathrm{Y}=\mathrm{a}+\mathrm{b}_{1} \mathrm{X}_{1}+\mathrm{b}_{2} \mathrm{X}_{2}$. $\mathrm{a}=$ angka konstan dari Unstandardized Coefficients. Untuk mengetahui nilai koefisien regresi ini dapat berpedoman pada output yang berada pada tabel coefficient. Untuk memastikan apakah koefisien regresi tersebut signifikan atau tidak yang dilakukan dengan cara membanding nilai signifikan dengan nilai probabilitas 0.05 . Jika nilai signifikan (sig.) lebih kecil $<$ dari nilai probabilitas 0.05 , maka terdapat pengaruh variabel $\mathrm{X}$ atau variabel bebas terhadap variabel $Y$ atau variabel terikat. Namun Jika nilai signifikan (sig.) lebih besar $>$ dari nilai probabilitas 0.05 , maka tidak ada pengaruh variabel $\mathrm{X}$ atau atau variabel bebas terhadap variabel $\mathrm{Y}$ atau variabel terikat.

Tabel 1. Koefisien

\begin{tabular}{|l|c|c|c|c|}
\hline Coefficients $^{\mathbf{a}}$ & \multicolumn{4}{|l|}{} \\
\hline Model & $\begin{array}{c}\text { Unstandardized } \\
\text { Coefficients }\end{array}$ & $\begin{array}{c}\text { Standardized } \\
\text { Coefficients }\end{array}$ & t & Sig. \\
\hline
\end{tabular}




\begin{tabular}{|l|l|r|r|r|r|r|}
\hline & \multicolumn{1}{|c|}{ B } & Std. Error & \multicolumn{1}{|c|}{ Beta } & & \\
\hline 1 & (Constant) & 81.289 & 6.298 & & 12.907 & .000 \\
\hline $\begin{array}{l}\text { Lingkungan } \\
\text { (XI) }\end{array}$ & .009 & .057 & .035 & .153 & .880 \\
\hline & Online (X2) & .024 & .082 & .067 & .297 & .769 \\
\hline $\begin{array}{l}\text { a. Dependent Variable: Hasil } \\
\text { (Y) }\end{array}$ & & & & \\
\hline
\end{tabular}

Berdasarkan tabel di atas terlihat nilai konstan Media Pembelajaran PAI Berbasis Lingkungan dan Berbasis Online sebesar 81.289. Nilai konstan ini memiliki arti, jika tidak ada Media Pembelajaran PAI Berbasis Lingkungan dan Berbasis Online (X1 dan X2), maka nilai konsisten Hasil Belajar Peserta didik (Y) sebesar 81.289. Nilai koefisien regresi Media Pembelajaran PAI Berbasis Lingkungan adalah sebesar 0.009. Nilai ini mengandung arti bahwa setiap terjadi peningkatan $1 \%$ penggunaan Media Pembelajaran PAI Berbasis Lingkungan di SD Negeri 09 Enam Lingkung Kabupaten Padang Pariaman, maka Hasil Belajar PAI peserta didik SD Negeri 09 Enam Lingkung Kabupaten Padang Pariaman akan meningkat sebesar 0.9\%. Sedangkan Nilai koefisien regresi Media Pembelajaran PAI Berbasis Online adalah sebesar 0.024. Nilai ini mengandung arti bahwa setiap terjadi peningkatan 1\% penggunaan Media Pembelajaran PAI Berbasis Online di SD Negeri 09 Enam Lingkung Kabupaten Padang Pariaman, maka Hasil Belajar PAI peserta didik SD Negeri 09 Enam Lingkung Kabupaten Padang Pariaman akan meningkat sebesar 2.4\%. Karena nilai koefisien, baik nilai koefisien Media Pembelajaran PAI Berbasis Lingkungan dan nilai koefisien Media Pembelajaran PAI Berbasis Online bernilai positif $(+)$, maka dapat dikatakan bahwa Media Pembelajaran PAI Berbasis Lingkungan dan Media Pembelajaran PAI Berbasis Online berpengaruh positif terhadap Hasil Belajar PAI peserta didik.

Berdasarkan tabel di atas diketahui nilai signifikan (sig.) Media Pembelajaran PAI Berbasis Lingkungan sebesar 0.880 lebih besar dari $>$ nilai probabilitas 0.05, dengan demikian dapat disimpulkan bahwa $\mathrm{H}_{\mathrm{o}}$ diterima dan $\mathrm{H}_{\mathrm{a}}$ ditolak. Hal ini berarti tidak terdapat pengaruh Media Pembelajaran PAI Berbasis Lingkungan terhadap Hasil Belajar peserta didik di SD Negeri 09 Enam Lingkung Kabupaten Padang Pariaman. Sedangkan nilai signifikan (sig.) Media Pembelajaran PAI Berbasis Online sebesar 0.769 lebih besar dari $>$ nilai probabilitas 0.05 , dengan demikian dapat disimpulkan bahwa $\mathrm{H}_{\mathrm{o}}$ diterima dan $\mathrm{H}_{\mathrm{a}}$ ditolak. Hal ini berarti tidak terdapat pengaruh Media Pembelajaran PAI Berbasis Online terhadap Hasil Belajar peserta didik di SD Negeri 09 Enam Lingkung Kabupaten Padang Pariaman.

Uji Parsial (Uji T) dilakukan dengan membandingkan nilai $T_{\text {hitung }}$ dengan nilai $T_{\text {tabel }}$ untuk mengetahui pengaruh variabel $\mathrm{X}$ atau variabel bebas terhadap variabel $\mathrm{Y}$ atau variabel terikat secara parsial. Jika nilai $T_{\text {hitung }}$ lebih besar $>$ dari nilai $T_{\text {tabel }}$, maka dapat disimpulkan bahwa terdapat pengaruh variabel X1 dan X2 atau variabel bebas terhadap variabel $\mathrm{Y}$ atau variabel terikat secara parsial. Namun Jika nilai $T_{\text {hitung }}$ lebih kecil < dari nilai nilai $T_{\text {tabel }}$, maka dapat disimpulkan bahwa tidak terdapat pengaruh variabel X1 dan X2 atau variabel bebas terhadap variabel $\mathrm{Y}$ atau variabel terikat secara parsial. 
Tabel 2. Annova

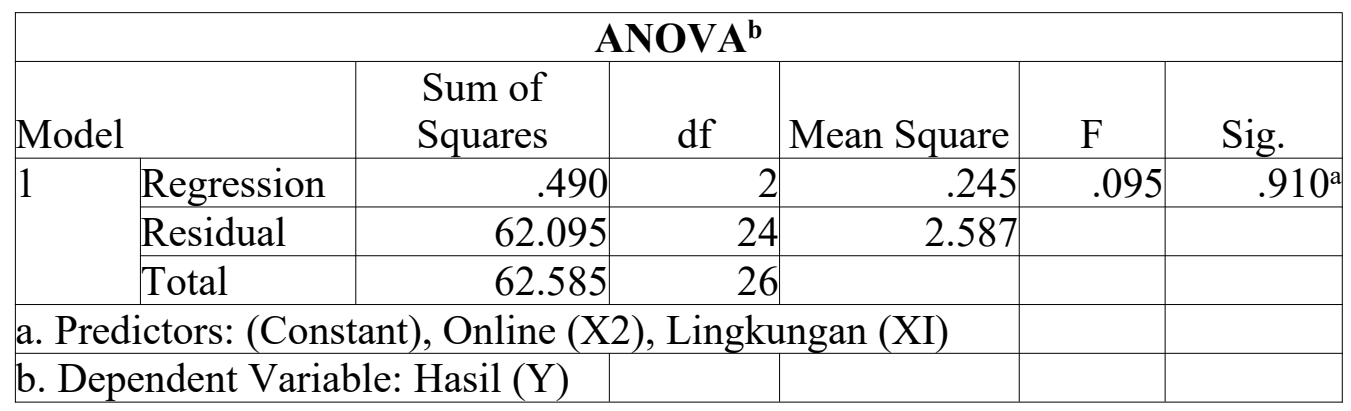

Berdasarkan tabel Annova di atas, diketahui nilai $f_{\text {hitung }}$ Media Pembelajaran PAI Berbasis Lingkungan dan Media Pembelajaran PAI Berbasis Online sebesar 0.095. untuk mencari nilai $f_{\text {tabel }}$ dapat dilihat pada tabel statistik dengan derajat kebebasan (df) $=\mathrm{n}-2-1=27-2-1=24$. Untuk melihat nilai $f_{\text {tabel }}$ dapat dilihat pada tabel F statistik urut ke 24 dengan nilai sebesar 1.98. Nilai $f_{\text {hitung }}$ sebesar $0.095<$ dari nilai $f_{\text {tabel }}$ sebesar 1.98, maka dapat disimpulkan $\mathrm{H}_{\mathrm{o}}$ diterima dan $\mathrm{H}_{\mathrm{a}}$ ditolak. Hal ini berarti tidak terdapat pengaruh Media Pembelajaran PAI Berbasis Lingkungan dan Media Pembelajaran PAI Berbasis Online secara simultan terhadap Hasil Belajar peserta didik di SD Negeri 09 Enam Lingkung Kabupaten Padang Pariaman.

\section{Pembahasan Hasil Penelitian}

Di Sekolah Dasar penggunaan media pada pembelajaran menjadi bagian yang sangat urgen dan harus menjadi perhatian para guru. Hal ini disebabkan karena input peserta didik pada tingkat dasar memiliki kemampuan terbatas sehingga menjadi penting diperhatikan dengan seksama media pembelajaran yang digunakan dalam pembelajaran di Sekolah Dasar (Akbar et al., 2020). Kompetensi dasar yang harus dimiliki oleh peserta didik pada tingkat Sekolah Dasar adalah sekurang-kurangnya memiliki kemampuan membaca, menulis, dan berhitung untuk dijadikan modal utama dan modal pokok untuk dapat melanjutkan pendidikan pada jenjang pendidikan yang lebih tinggi. Agar peserta didik dapat mengikuti kegiatan pendidikan ditingkat yang lebih tinggi tersebut, maka peserta didik harus dibekali dengan tiga kemampuan dasar tersebut. Tetapi kenyataan menunjukkan bahwa kebanyakan peserta didik yang duduk di kelas rendah Sekolah Dasar belum memiliki kemampuan yang memadai untuk membaca sumber belajar melalui buku untuk semua mata pelajaran. Sementara untuk menguasai mata pelajaran peserta didik harus telah mampu membaca buku sumber pelajaran tersebut.

Keterbatasan kemampuan membaca peserta didik di tingkat Sekolah Dasar mengharuskan guru menggunakan media pembelajaran agar peserta didik dapat memahami materi yang akan disampaikan (Arum \& Suprapto, 2021). Hal ini didasarkan pada pertimbangan bahwa kesulitan yang sering dihadapi oleh peserta didik Sekolah Dasar dalam mengikuti kegiatan pembelajaran untuk mata pelajaran sains adalah karena ketidakmampuan peserta didik Sekolah Dasar membaca sehingga sulit memahami isi materi pelajaran selain yang disampaikan guru secara lisan.

Karena rendahnya kemampuan peserta didik membaca, maka dalam mengajarkan materi pelajaran perlu digunakan media pembelajaran yang dapat membantu peserta didik untuk memahami materi pelajaran yang disampaikan oleh guru. Media pembelajaran yang dapat dipergunakan oleh guru diantaranya adalah grafis, 
media tiga dimensi, dan media proyeksi. Seperti diketahui bahwa media pembelajaran adalah merupakan merupakan alat bantu yang dipergunakan untuk melakukan visualisasi dalam proses belajar mengajar agar proses belajar mengajar tersebut dapat berlangsung secara efektif. Karena keterbatasan kemampuan peserta didik membaca dalam mata pelajaran sains, maka guru perlu menggunakan media pembelajaran berupa grafis, media tiga dimensi, dan media proyeksi yang dapat membantu peserta didik untuk memahami materi dan isi pelajaran yang disampaikan oleh guru dalam kegiatan pembelajaran.

Di SD Negeri 09 Enam Lingkung Kabupaten Padang Pariaman, Guru Pendidikan Agama Islam (PAI) telah menggunakan Media Pembelajaran Berbasis Lingkungan dan Berbasis Online dalam pembelajaran Pendidikan Agama Islam (PAI). Melalui penggunaan media ini membuat peserta didik lebih bersemangat dan memiliki keinginan untuk memahami dan mengetahui materi pembelajaran.

\section{Media Pembelajaran PAI Berbasi Lingkungan}

Berdasarkan hasil jawaban responden penelitian, yaitu peserta didik Kelas V dan VI Tahun Pelajaran 2020/2021 bahwa pemanfaatan Media Pembelajaran PAI Berbasis Lingkungan berjalan dengan sangat baik. Pemanfaatan Media Pembelajaran PAI Berbasis Lingkungan di SD Negeri 09 Enam Lingkung Kabupaten Padang Pariaman ini tidak bisa peneliti observasi atau diamati, karena pelaksanaan proses pembelajaran pada massa Covid-19 dilaksanakan dalam bentuk BDR (Dilaksankan Belajar di Rumah). Namun pada studi dokumentasi peneliti menemukan beberapa tulisan atau dokumen yang menunjukkan pelaksanaan pembelajaran Pendidikan Agama Islam dengan memanfaatkan Media Pembelajaran PAI Berbasis Lingkungan di SD Negeri 09 Enam Lingkung Kabupaten Padang Pariaman.

Di dalam dokumen tersebut peneliti menemukan langkah-langkah pemanfaatan Media Pembelajaran PAI Berbasis Lingkungan di SD Negeri 09 Enam Lingkung Kabupaten Padang Pariaman. Menurut analisa penulis bahwa guru PAI SD Negeri 09 Enam Lingkung Kabupaten Padang Pariaman telah memaksimalkan pemanfaatan lingkungan sebagai media belajar atau sumber belajar (Tiara et al., 2020), namun dalam dokumen tersebut peneliti tidak menemukan cara guru PAI SD Negeri 09 Enam Lingkung Kabupaten Padang Pariaman mengevaluasi pemanfaatan lingkungan sebagai media belajar atau sumber belajar. Evaluasi ini menjadi penting karena melalui evaluasi guru PAI SD Negerii 09 Enam Lingkung Kabupaten Padang Pariaman dapat menyeleksi, mendiagnosa, dan mengukur keberhasil pemanfaatan lingkungan sebagai media belajar atau sumber belajar.

Walaupun pemanfaatan media pembelajaran berbasis lingkungan di SD Negeri 09 Enam Lingkung Kabupaten Padang Pariaman, namun berdasarkan output SPSS pada tabel koefisien, variabel ini hanya mampu menyumbang 0,9\% terhadap Hasil Belajar Peserta Didik. Hal ini bisa dilihat dari nilai konstan Media Pembelajaran PAI Berbasis Lingkungan sebesar 81.289. Nilai konstan ini memiliki arti, jika tidak ada Media Pembelajaran PAI Berbasis Lingkungan (X1), maka nilai konsisten Hasil Belajar Peserta didik (Y) sebesar 81.289. Artinya Hasil Belajar PAI peserta didik telah berjalan dengan baik tanpa menggunakan media pembelajaran berbasis lingkungan. Namun berdasarkan Nilai koefisien regresi terdapat nilai Media Pembelajaran PAI Berbasis Lingkungan sebesar 0.009. Nilai ini mengandung arti bahwa setiap terjadi peningkatan 1\% penggunaan Media Pembelajaran PAI Berbasis Lingkungan di SD Negeri 09 Enam Lingkung Kabupaten Padang Pariaman, maka Hasil Belajar PAI peserta didik akan meningkat sebesar $0.9 \%$. Karena nilai koefisien Media Pembelajaran PAI Berbasis Lingkungan bernilai positif (+), maka dapat dikatakan bahwa Media Pembelajaran PAI Berbasis Lingkungan berpengaruh positif terhadap Hasil Belajar PAI peserta didik.

\section{Media Pembelajaran PAI Berbasi Online}

Berdasarkan hasil jawaban responden penelitian, yaitu peserta didik Kelas V dan VI Tahun Pelajaran 2020/2021 bahwa pemanfaatan Media Pembelajaran PAI Berbasis Online berjalan dengan sangat baik. Berdasarkan hasil observasi atau pengamatan dan 
studi dokumentasi yang peneliti lakukan di SD Negeri 09 Enam Lingkung Kabupaten Padang Pariaman bahwa pelaksanaan proses pembelajaran pada massa Covid-19 dilaksanakan dalam bentuk BDR dan para guru tetap hadir ke sekolah dengan mentaati protokol kesehatan yang telah ditetapkan. Guru PAI SD Negeri 09 Enam Lingkung Kabupaten Padang Pariaman melaksanakan pembelaran melalui jaringan secara online.

Pembelajaran PAI dengan memanfaatkan Media Berbasis Online yang dilaksanakan oleh guru PAI SD Negeri 09 Enam Lingkung Kabupaten Padang Pariaman berjalan dengan sangat baik, dengan menyesuaikan kondisi peserta didik itu sendiri. Berdasarkan output SPSS Versi 20.0 terlihat bahwa Media Pembelajaran Berbasis Online di SD Negeri 09 Enam Lingkung Kabupaten Padang Pariaman, hanya mampu menyumbang sebesar 2.49\% terhadap Hasil Belajar Peserta Didik. Hal ini bisa dilihat dari nilai konstan Media Pembelajaran PAI Berbasis Lingkungan sebesar 81.289. Nilai konstan ini memiliki arti, jika tidak ada Media Pembelajaran PAI Berbasis Berbasis Online (X2), maka nilai konsisten Hasil Belajar Peserta didik (Y) sebesar 81.289.

Artinya Hasil Belajar PAI peserta didik telah berjalan dengan baik tanpa menggunakan media pembelajaran berbasis online. Namun berdasarkan Nilai koefisien regresi Media Pembelajaran PAI Berbasis Online adalah sebesar 0.024. Nilai ini mengandung arti bahwa setiap terjadi peningkatan 1\% penggunaan Media Pembelajaran PAI Berbasis Online di SD Negeri 09 Enam Lingkung Kabupaten Padang Pariaman, maka Hasil Belajar PAI peserta didik SD Negeri 09 Enam Lingkung Kabupaten Padang Pariaman akan meningkat sebesar 2.4\%. Karena nilai koefisien Media Pembelajaran PAI Berbasis Online bernilai positif $(+)$, maka dapat dikatakan bahwa Media Pembelajaran PAI Berbasis Online berpengaruh positif terhadap Hasil Belajar PAI peserta didik.

Temuan penelitian in mendukung hasil penelitian yang menyatakan bahwa media berbasis online memiliki dampak untuk meningkatkan hasil pembelajaran. Hayyu menjelaskan bahwa tanpa adanya media yang berbasis online pembelajaran dalam kondisi sulit seperti covid-19 tidak akan mungkin dapat dilangsungkan (Hayyu, 2021), Warni dan kawan-kawan juga mengungkapkan bahwa keberadaan media berbasis online menjadi penghubung antara peserta didik dengan pendidik, sehingga materi pembelajaran tetap tersampaikan walaupun tidak bertatap muka (Warni et al., 2021).

\section{Hasil Belajar Pendidikan Agama Islam}

Berdasarkan Hasil Belajar peserta didik Kelas V dan VI SD Negeri 09 Enam Lingkung Kabupaten Padang Pariaman Tahun Pelajaran 2020/2021 yang diambil dari nilai ranah afektif, kognitif, dan psikomotorik dengan nilai rata-rata baik. Bedasarkan output SPSS Versi 20.0 diperoleh nilai konstan sebesar 81.289 atau 81,29\%. Nilai konstan ini memiliki arti bahwa Hasil Belajar PAI peserta didik telah berjalan dengan baik tanpa menggunakan media pembelajaran berbasis online.

Berdasarkan nilai signifikan (sig.) Media Pembelajaran PAI Berbasis Lingkungan dan Media Pembelajaran PAI Berbasis Online tidak memiliki pengaruh terhadap Hasil Belajar peserta didik di SD Negeri 09 Enam Lingkung Kabupaten Padang Pariaman. Secara parsial, Media Pembelajaran PAI Berbasis Lingkungan dan Media Pembelajaran PAI Berbasis Online tidak memiliki pengaruh terhadap Hasil Belajar peserta didik di SD Negeri 09 Enam Lingkung Kabupaten Padang Pariaman. Sedangkan Secara simultan (secara bersama-sama) Media Pembelajaran PAI Berbasis Lingkungan dan Media Pembelajaran PAI Berbasis Online tidak memiliki pengaruh 
terhadap Hasil Belajar peserta didik di SD Negeri 09 Enam Lingkung Kabupaten Padang Pariaman.

Walaupun pemanfaatan Media Media Pembelajaran PAI Berbasis Lingkungan dan Media Pembelajaran PAI Berbasis Online telah terlaksana dengan sangat baik di SD Negeri 09 Enam Lingkung Kabupaten Padang Pariaman, namun kedua media pembelajaran ini tidak memiliki pengaruh yang signifikan terhadap hasil belajar PAI peserta didik. Jika dibandingkan dengan nilai rata-rata Hasil Belajar Peserta di SD Negeri 09 Enam Lingkung Kabupaten Padang Pariaman, ternyata Hasil Belajar Peserta didik berada pada rata-rata yang sangat baik, yaitu 83.75 , namun perolehan nilai ratarata Hasil Belajar peserta didik ini tidak dipengaruhi secara signifikan oleh media pembelajaran yang digunakan oleh guru PAI. Pengaruh kedua media pembelajaran ini terhadap Hasil Belajar peserta didik hanya 0.09\% dari Media Pembelajaran PAI Berbasis Lingkungan dan 2.4\% dari Media Pembelajaran PAI Berbasis Online. Hal ini menunjukkan Media Media Pembelajaran PAI Berbasis Lingkungan dan Media Pembelajaran PAI Berbasis Online tidak memiliki pengaruh yang signifikan terhadap Hasil Belajar peserta didik.

Berdasarkan beberapa pendapat yang telah dikemukakan para ahli di atas, tergambar urgensi media pembelajaran dalam proses belajar-mengajar, baik dari sisi fungsi, manfaat dan nilai media pembelajaran. Pemanfaatan media pembelajaran akan memudahkan guru dalam melaksanakan proses pembelajaran yang memungkinkan terjadinya pengalaman belajar pada diri peserta didik dengan menggerakkan segala sumber belajar yang efektif dan efisien (Putri et al., 2021). Media pembelajaran yang digunakan akan membuat peserta didik merasa tertarik terhadap materi yang diajarkan sehingga proses pembelajaran tidak terkesan membosankan.

Media pembelajaran akan memperlancar interaksi antara guru dengan peserta didik, sehingga kegiatan pembelajaran akan lebih efektif dan efesien. Belajar tidak selamanya berhubungan dengan hal-hal yang konkrit, baik dalam konsep maupun faktanya. Bahkan dalam realitanya, belajar seringkali bersentuhan dengan hal-hal yang bersifat kompleks, maya dan berada dibalik realitas. Ketidakjelasan atau kerumitan bahan ajar dapat dibantu dengan menghadirkan media pembelajaran sebagai perantara. Bahkan dalam hal-hal tertentu media pembelajaran akan dapat mewakili kelemahan dan kekurangan guru dalam mengkomunikasikan materi pelajaran.

\section{CONCLUSIONS}

Berdasarkan hasil penelitian yang telah diuraikan sebelumnya, maka hasil penelitian ini dapat disimpulkan: pertama, Pelaksanaan pembelajaran Pendidikan Agama Islam dengan menggunakan Media Pembelajaran Berbasis Lingkungan berjalan dengan sangat baik. Kedua, Pelaksanaan pembelajaran Pendidikan Agama Islam dengan menggunakan Media Pembelajaran Berbasis Online terlaksana dengan sangat baik. Ketiga, Media Pembelajaran Berbasis Lingkungan dan Berbasis Online tidak memiliki pengaruh yang signifikan terhadap Hasil Belajar Pendidikan Agama Islam peserta didik, baik secara parsial maupun secara simultan. Hal ini dapat dilihat pada nilai signifikan (sig.) Media Pembelajaran PAI Berbasis Lingkungan sebesar 0.880 lebih besar dari > nilai probabilitas 0.05 , dan nilai signifikan (sig.) Media Pembelajaran PAI Berbasis Online sebesar 0.769 lebih besar dari $>$ nilai probabilitas 0.05 . Dengan demikian dapat 
disimpulkan bahwa $\mathrm{H}_{\mathrm{o}}$ diterima dan $\mathrm{H}_{\mathrm{a}}$ ditolak. Hal ini berarti Media Pembelajaran PAI Berbasis Lingkungan dan Online tidak memiliki pengaruh yang signifikan terhadap Hasil Belajar peserta didik di SD Negeri 09 Enam Lingkung Kabupaten Padang Pariaman.

\section{BIBILIOGRAPHY}

Akbar, Y. F., Rizal, A., Tiara, Islami, N. N., \& Hartanto, W. (2020). The urgency of using online-based learning media to enhance students' self-directed learning and result study on accounting chapter of economics subjects. IOP Conference Series: Earth and Environmental Science, 485(1), 6-11. https://doi.org/10.1088/1755$1315 / 485 / 1 / 012137$

Andria Rosa, Mahyudin Ritonga, \& Wedy Nasrul. (2020). Penggunaan Media Berbasis Teknologi Dalam Pembelajaran Pendidikan Agama Islam Di Sekolah Menengah Pertama Negeri. Jurnal Islamika, 3(2), 36-43. https://doi.org/10.37859/jsi.v3i2.2136

Arum, A., \& Suprapto, N. (2021). Nomographic Technique Development on Global Warming Material for High School Student Grade Eleven of Literacy Class. International Journal of Active Learning, 6(1), 1-8. https://www.learntechlib.org/p/218682/

Grabinger, R. S., \& Dunlap, J. C. (1995). Rich environments for active learning: a definition. Alt-J, 3(2), 5-34. https://doi.org/10.1080/0968776950030202

Hayyu, Z. (2021). The Influence of Online Learning on Motivation and Learning Outcomes of the Qur'an Hadith in MAN 1 Pasaman. Ruhama: Islamic Education Journal, 4(1), 1-15.

Khaira, M., Ritonga, M., \& Halim, S. (2021). The Effectiveness of Scrabble Game Media in Improving Learning Outcomes. Journal of Physics: Conference Series, 1933(1), 012128. https://doi.org/10.1088/1742-6596/1933/1/012128

Mardikaningrum, K., Supriyadi, S., \& Sudiyanto. (2017). The Need of Learning Media Arts in Junior High (Study on Grade Vii Students of Junior High School Negeri 1 Mojolaban ). Proceeding of 2nd International Conference of Arts Language And Culture, 1, 323-327.

Marpanaji, E., Mahali, M. I., \& Putra, R. A. S. (2018). Survey on How to Select and Develop Learning Media Conducted by Teacher Professional Education Participants. Journal of Physics: Conference Series, 1140(1). https://doi.org/10.1088/1742-6596/1140/1/012014

Putri, A. H., Permatasari, F. E., Hijriyah, A. L., \& Mauludiyah, L. (2021). Arabic Quizzes Game to Improve Arabic Vocabulary. Tanwir Arabiyyah: Arabic as Foreign Language Journal, 1(1), 45-54. 
https://doi.org/https://doi.org/10.22219/afl.v1i1.2484

Ramdhani, M. A., \& Muhammadiyah, H. (2015). Proceeding International Conference of Islamic Education: Reforms, Prospects and Challenges Faculty of Tarbiyah and Teaching Training The Criteria of Learning Media Selection for Character Education in Higher Education. Proceeding International Conference of Islamic Education: Reforms, Prospects and Challenges Faculty of Tarbiyah and Teaching Training The Criteria of Learning Media Selection for Character Education in Higher Education, 174-182.

Risnawati, Amir, Z., \& Sari, N. (2018). The development of learning media based on visual, auditory, and kinesthetic (VAK) approach to facilitate students' mathematical understanding ability. Journal of Physics: Conference Series, 1028(1). https://doi.org/10.1088/1742-6596/1028/1/012129

Ritonga, A. W., Ritonga, M., Septiana, V. W., \& Mahmud. (2021). Crossword puzzle as a learning media during the covid-19 pandemic: HOTS, MOTS or LOTS? Journal of Physics: Conference Series, 1933(1), 012126. https://doi.org/10.1088/1742$6596 / 1933 / 1 / 012126$

Sartika, F., Desriwita, E., \& Ritonga, M. (2020). Pemanfaatan Media Pembelajaran Dalam Meningkatkan Kualitas Pembelajaran PAI di Sekolah. Humanika, Kajian Ilmiah Mata Kuliah Umum, 20(2), 115-128. https://doi.org/10.21831/hum.v20i2.32598

Susanti, E., Ritonga, M., \& Bambang, B. (2020). Pengaruh Penggunaan Media Powerpoint Terhadap Minat Belajar Bahasa Arab Siswa. Arabiyatuna: Jurnal Bahasa Arab, 4(1), 179-191. https://doi.org/10.29240/jba.v4i1.1406

Thompson, C. M., Anttila, E., Ruthmann, S. A., Doan, W. J., \& Black, J. (2014). International Journal of Education \& the Arts Editors Model New Media/Video Programs in Arts Education: Case Study Research. International Journal of Education \& the Arts, 15(6), 1-26. http://www.ijea.org/v15n6/.

Tiara, Nofrianti, L., Habibi, M., Musdizal, Putra, A., Angela, L., Seprianto, Adelia, I., \& Lardiman, H. (2020). Utilization of environment as a learning media or natural science study in junior high schools. International Journal of Scientific and Technology Research, 9(2), 1981-1983.

Warni, L., Saputra, R., \& Rasyid, A. (2021). The Use of “ Rumah Belajar” in PAI Lea rning during Covid- 19 at Marhamah Elementary School. Ruhama: Islamic Education Journal, 4(1), 1-13. https://doi.org/10.31869/ruhama.v4i12618

Yanuari Dwi Puspitarini, \& Hanif, M. (2019). Using Learning Media to Increase Learning Motivation in Elementary School. Anatolian Journal of Education, 4(2), 53-60. https://doi.org/10.29333/aje.2019.426a 
